\title{
Lactobacillus cypricasei Lawson et al. 2001 is a later heterotypic synonym of Lactobacillus acidipiscis Tanasupawat et al. 2000
}

\author{
Sabri M. Naser, ${ }^{1,2}$ Marc Vancanneyt, ${ }^{2}$ Bart Hoste, ${ }^{2}$ Cindy Snauwaert ${ }^{2}$ \\ and Jean Swings ${ }^{1,2}$ \\ Laboratory of Microbiology ${ }^{1}$ and BCCM ${ }^{\mathrm{TM}} / \mathrm{LMG}$ Bacteria Collection², Ghent University, \\ K.L. Ledeganckstraat 35, Ghent 9000, Belgium
}

Correspondence

Sabri M. Naser

Sabri.Naser@Ugent.be

\begin{abstract}
The applicability of a multilocus sequence analysis (MLSA)-based identification system for lactobacilli was evaluated. Two housekeeping genes that code for the phenylalanyl-tRNA synthase $\alpha$-subunit (pheS) and RNA polymerase $\alpha$-subunit (rpoA) were sequenced and analysed for members of the Lactobacillus salivarius species group. The type strains of Lactobacillus acidipiscis and Lactobacillus cypricasei were investigated further using a third gene that encodes the $\alpha$-subunit of ATP synthase (atpA). The MLSA data revealed close relatedness between $L$. acidipiscis and $L$. cypricasei, with 99-8-100\% pheS, rpoA and atp $A$ gene sequence similarities. Comparison of the 16S rRNA gene sequences of the type strains of the two species confirmed the close relatedness (99.8\% gene sequence similarity) between the two taxa. Similar phenotypes and high DNA-DNA binding values in the range of 84 to $97.5 \%$ confirmed that $L$. acidipiscis and L. cypricasei are synonymous species. On the basis of the present study, it is proposed that Lactobacillus cypricasei is a later heterotypic synonym of Lactobacillus acidipiscis.
\end{abstract}

Lactobacillus acidipiscis was described by Tanasupawat et al. (2000) based on 11 strains isolated from fermented fish (plara and pla-chom) in Thailand. L. acidipiscis utilizes Dglucose homofermentatively and produces L-lactic acid from glucose without the production of gas. L. acidipiscis strains do not grow at $\mathrm{pH} 4 \cdot 0$ or $8 \cdot 5$ and grow in $10 \% \mathrm{NaCl}$. Phylogenetic analysis based on $16 \mathrm{~S}$ rRNA gene sequences showed that $L$. acidipiscis strains are positioned in a monophyletic cluster consisting of Lactobacillus salivarius, Lactobacillus aviarius, Lactobacillus ruminis, Lactobacillus agilis, Lactobacillus murinus, Lactobacillus animalis and Lactobacillus mali. The DNA-DNA relatedness of L. acidipiscis strains and other related Lactobacillus species was found to be in the

\footnotetext{
Abbreviation: MLSA, multilocus sequence analysis.

The GenBank/EMBL/DDBJ accession numbers for the partial pheS gene sequences for strains LMG 19820', LMG 21592', LMG 23135, CCUG 42959, CCUG 42960, CCUG 42962, LMG 9843'', LMG $14189^{\top}$, LMG $22087^{\top}$, LMG $21748^{\top}$, LMG $9186^{\top}$, LMG $10753^{\top}$, LMG $10756^{\top}$, LMG 21593 ${ }^{\top}$, LMG $9477^{\top}$, LMG 6899 ${ }^{\top}$ and LMG $6903^{\top}$ are AM087762, AM087687, AM168426-AM168429, AM087679, AM087760, AM087717, AM087740, AM087734, AM087737, AM087756, AM087708, AM087721, AM087746 and AM168425. Those for the rpoA partial gene sequences for strains LMG $19820^{\top}$, LMG 21592 ${ }^{\top}$, LMG 23135, CCUG 42959, CCUG 42960, LMG $9186^{\top}$ and LMG 14189 ${ }^{\top}$ are AM087849, AM087784, AM168431AM168433, AM087831 and AM087801, respectively. Those for the atpA partial gene sequences for strains LMG $19820^{\top}$ and LMG $21592^{\top}$ are AM168424-AM168423, respectively.
}

range of $3 \cdot 6$ to $26 \cdot 7 \%$ (Tanasupawat et al., 2000). One year later, Lactobacillus cypricasei was described by Lawson et al. (2001) based on four strains isolated from Halloumi, a cheese produced in Cyprus. The strains were Gram-positive, non-spore-forming, facultatively anaerobic and catalaseand oxidase-negative. No growth was observed at 15 or $45^{\circ} \mathrm{C}$. Like L. acidipiscis, L. cypricasei strains formed a distinct branch within the $L$. salivarius species group, with $L$. salivarius and $L$. aviarius as the nearest neighbours. However, Lawson et al. (2001) did not include the related recognized species $L$. acidipiscis in comparisons with other species. In the present study, the relatedness between $L$. acidipiscis and L. cypricasei strains was investigated and revealed synonymy between the two taxa.

Two reference strains of L. acidipiscis, LMG $19820^{\mathrm{T}}$ and LMG 23135, and four reference strains of L. cypricasei, LMG 21592 ${ }^{\mathrm{T}}$, CCUG 42959, CCUG 42960 and CCUG 42962, were selected for further comparative study. L. cypricasei LMG $21592^{\mathrm{T}}$ was cultivated and maintained on de Man, Rogosa and Sharpe medium (MRS; Difco). All other strains studied were cultivated and maintained on MRS (Oxoid) medium and incubated anaerobically at $37^{\circ} \mathrm{C}$, unless otherwise indicated.

The use of protein-coding gene sequence data for the determination of genomic relatedness at the bacterial species and genus levels has recently been advocated because of its ability to provide higher taxonomic resolution, since $16 \mathrm{~S}$ rRNA 
gene sequence analysis may not be sufficiently specific to discriminate between closely related species (Chavagnat et al., 2002; Stackebrandt et al., 2002; Torriani et al., 2001; Ventura et al., 2003; Zeigler, 2003). Recently, the application of multilocus sequence analysis (MLSA) using the genes that code for the $\alpha$-subunit of bacterial phenylalanyl-tRNA synthase (pheS), the $\alpha$-subunit of RNA polymerase $(r p o A)$ and the $\alpha$-subunit of ATP synthase (atpA) provided a robust system for the identification of Enterococcus species (Naser et al., 2005a, b). The MLSA-based identification system has proved to be valuable for the detection of synonymous species names within the genus Enterococcus (Naser et al., 2006b). In addition, relatedness between strains of Lactobacillus helveticus and Lactobacillus suntoryeus was initially evaluated using the same MLSA loci. Naser et al. (2006a) demonstrated that Lactobacillus suntoryeus is a later synonym of Lactobacillus helveticus. The pheS and rpoA genes were subsequently used for the analysis of lactobacilli of the L. salivarius species group, including the two strains of $L$. acidipiscis and the four reference strains of $L$. cypricase $i$. The type strains of L. acidipiscis and L. cypricasei were further investigated using the atpA gene. The primer sequences, amplification conditions and sequencing reactions were as described by Naser et al. (2005a, b). Raw sequence data were transferred to GeneBuilder (Applied Maths) where consensus sequences were determined. Consensus sequences were imported into BioNumerics 4.0 software (Applied Maths). The determined partial pheS and rpoA gene sequences (453 and $402 \mathrm{bp}$, respectively) were compared for the two L. acidipiscis strains (LMG $19820^{\mathrm{T}}$ and LMG 23135), four L. cypricasei strains (LMG $21592^{\mathrm{T}}$, CCUG 42959, CCUG 42960 and CCUG 42962) and other members of the $L$. salivarius species group. Comparison of the sequences of the strains of $L$. cypricasei and $L$. acidipiscis revealed pheS and rpoA gene sequence similarities in the range of $99 \cdot 8$ to $100 \%$. The atpA partial gene sequences of $L$. cypricasei LMG $21592^{\mathrm{T}}$ (GenBank accession no. AM168423) and L. acidipiscis LMG $19820^{\mathrm{T}}$ (AM168424) were also compared (976 bp) and showed high relatedness. Strains of the two species had a maximum of $78 \%$ pheS gene sequence similarity with $L$. mali and L. murinus, $82 \%$ rpoA gene sequence similarity with $L$. agilis and $80 \%$ atpA gene sequence similarity with $L$. murinus (Fig. 1). Consequently, the MLSA data indicated that L. acidipiscis and L. cypricasei might represent a single species.

The phylogenetic relatedness between $L$. acidipiscis $\mathrm{FS} 60-1^{\mathrm{T}}$ and L. cypricasei CCUG $42961^{\mathrm{T}}$ was investigated by comparing the available $16 \mathrm{~S}$ rRNA gene sequences (L. acidipiscis GenBank accession no. AB023836, 1406 bp; L. cypricasei GenBank accession no. AJ251560, 1456 bp). The latter sequences and those of related species were retrieved from GenBank and aligned. A phylogenetic tree was constructed by the neighbour-joining method using BioNumerics software, version 4.0 (Applied Maths). Unknown bases were discarded for the analyses. Comparison of the sequences of the type strains of L. cypricasei and L. acidipiscis revealed $99 \cdot 8 \% 16 \mathrm{~S}$ rRNA gene sequence similarity.

In the original description of L. cypricasei, the authors did not determine the DNA $\mathrm{G}+\mathrm{C}$ content. In the present study, we investigated this characteristic for the type strain of $L$. cypricasei. Cells were cultivated in MRS broth at $37^{\circ} \mathrm{C}$ for $24 \mathrm{~h}$. DNA was extracted from $0 \cdot 5-0 \cdot 75 \mathrm{~g}$ (wet weight) by using the protocol described by Marmur (1961) with the following modifications: (i) cells were suspended overnight in Tris/ $\mathrm{HCl}$ buffer that contained lysozyme $\left(8 \mathrm{mg} \mathrm{ml}^{-1}\right)$ before the addition of SDS and (ii) lysed cells were treated with proteinase $\mathrm{K}\left(360 \mathrm{mg} \mathrm{l}^{-1}\right.$; Merck) at $37^{\circ} \mathrm{C}$ for $2 \mathrm{~h}$. For determination of the DNA $\mathrm{G}+\mathrm{C}$ content, DNA was degraded enzymically into nucleosides as described by Mesbah et al. (1989). The nucleoside mixture was then separated by HPLC using a SymmetryShield RP8 column (Waters) maintained at $37^{\circ} \mathrm{C}$. The solvent was $0.02 \mathrm{M}$ $\mathrm{NH}_{4} \mathrm{H}_{2} \mathrm{PO}_{4}(\mathrm{pH} 4.0)$ with $1.5 \%$ acetonitrile. Non-methylated $\lambda$-phage DNA (Sigma) was used as the calibration reference. The DNA G $+\mathrm{C}$ content of $L$. cypricasei $\mathrm{LMG}$ $21592^{\mathrm{T}}$ was $40 \cdot 1 \mathrm{~mol} \%$. In comparison, the DNA G $+\mathrm{C}$ content of $L$. acidipiscis LMG $19820^{\mathrm{T}}$ was $38 \cdot 7 \mathrm{~mol} \%$.

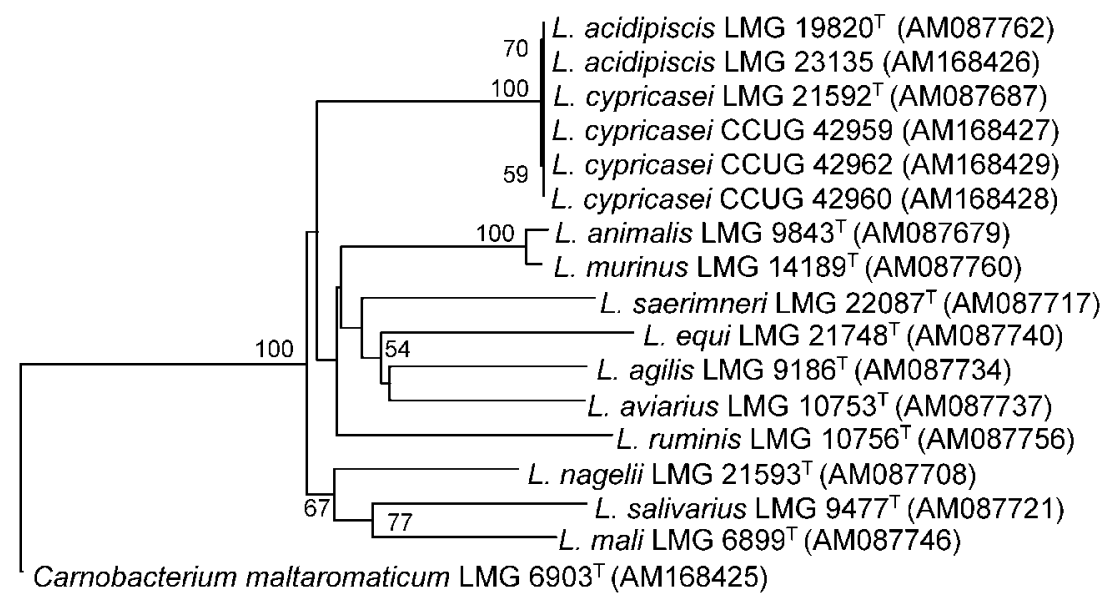

Fig. 1. Neighbour-joining tree based on the partial pheS gene sequences of $L$. cypricasei and $L$. acidipiscis strains. Carnobacterium maltaromaticum LMG $6903^{\top}$ was included as an outgroup. Bootstrap percentages ( $\geqslant 50 \%$ ) after 500 simulations are shown. Bar, $2 \%$ sequence divergence. 
Finally, DNA-DNA hybridizations were performed between L. cypricasei strains LMG $21592^{\mathrm{T}}$ and CCUG 42960 and $L$. acidipiscis strains LMG $19820^{\mathrm{T}}$ and LMG 23135. Genomic DNA was prepared according to the protocol of Pitcher et al. (1989) with the following modifications: the washed cell pellet was resuspended and lysed in a buffer $(10 \mathrm{mM}$ Tris/ $\mathrm{HCl}, 100 \mathrm{mM}$ EDTA, $\mathrm{pH} \mathrm{8.0)}$ that contained RNase (200 $\mu \mathrm{g} \mathrm{ml}^{-1}$; Sigma), mutanolysin $\left(100 \mathrm{U} \mathrm{ml}^{-1}\right.$; Sigma $)$ and lysozyme $\left(25 \mathrm{mg} \mathrm{ml}^{-1}\right.$; SERVA) for $1 \mathrm{~h}$ at $37^{\circ} \mathrm{C}$. The microplate method was used as described by Ezaki et al. (1989) and Goris et al. (1998) using a HTS7000 Bio Assay Reader (Perkin Elmer) for the fluorescence measurements. Biotinylated DNA was hybridized with unlabelled ssDNA, which was bound non-covalently to microplate wells. Hybridizations were performed at $36{ }^{\circ} \mathrm{C}$ in hybridization mixture $(2 \times$ SSC, $5 \times$ Denhardt's solution, $2.5 \%$ dextran sulfate, $50 \%$ formamide, $100 \mu \mathrm{g}$ denatured salmon sperm DNA $\mathrm{ml}^{-1}, 1250 \mathrm{ng}$ biotinylated probe DNA ml${ }^{-1}$ ). Reciprocal reactions (e.g. $\mathrm{A} \times \mathrm{B}$ and $\mathrm{B} \times \mathrm{A}$ ) were performed. The DNA-DNA binding values reported were the mean values of a minimum of four hybridization experiments, including the reciprocal reactions. L. acidipiscis strains LMG $19820^{\mathrm{T}}$ and LMG 23135 and L. cypricasei strains LMG $21592^{\mathrm{T}}$ and CCUG 42960 showed high DNA-DNA binding values in the range of 84 to $97.5 \%$, indicating clearly that the two taxa represent the same species. A DNA-DNA hybridization value of $93 \%$ was found between the type strains of the two species.

On the basis of the evidence presented, it is concluded that Lactobacillus cypricasei is a later heterotypic synonym of Lactobacillus acidipiscis. It is proposed that the two species be united under the same name. As a rule of priority (Rules 38 and 42 of the Bacteriological Code; Lapage et al., 1992), the name Lactobacillus acidipiscis should be retained and strains of Lactobacillus cypricasei should be reclassified as such. The description of $L$. acidipiscis remains essentially the same except for some strain-dependent reactions, such as the production of acid from mannitol and D-ribose and the production of arginine dihydrolase.

\section{Acknowledgements}

S.M.N. acknowledges a PhD scholarship from the Ministry of Education and Higher Education. J.S. acknowledges grants from of the Fund for Scientific Research (FWO), Belgium.

\section{References}

Chavagnat, F., Haueter, M., Jimeno, J. \& Casey, M. G. (2002). Comparison of partial tuf gene sequences for the identification of lactobacilli. FEMS Microbiol Lett 217, 177-183.

Ezaki, T., Hashimoto, Y. \& Yabuuchi, E. (1989). Fluorometric deoxyribonucleic acid-deoxyribonucleic acid hybridization in microdilution wells as an alternative to membrane filter hybridization in which radioisotopes are used to determine genetic relatedness among bacterial strains. Int J Syst Bacteriol 39, 224-229.
Goris, J., Suzuki, K., De Vos, P., Nakase, T. \& Kersters, K. (1998). Evaluation of a microplate DNA-DNA hybridization method compared with the initial renaturation method. Can J Microbiol 44, 1148-1153.

Lapage, S. P., Sneath, P. H. A., Lessel, E. F., Skerman, V. B. D., Seeliger, H. P. R. \& Clark, W. A. (editors) (1992). International Code of Nomenclature of Bacteria (1990 Revision). Bacteriological Code. Washington, DC: American Society for Microbiology.

Lawson, P. A., Papademas, P., Wacher, C., Falsen, E., Robinson, R. \& Collins, M. D. (2001). Lactobacillus cypricasei sp. nov., isolated from Halloumi cheese. Int J Syst Evol Microbiol 51, 45-49.

Marmur, J. (1961). A procedure for the isolation of deoxyribonucleic acid from microorganisms. J Mol Biol 3, 208-218.

Mesbah, M., Premachandran, U. \& Whitman, W. B. (1989). Precise measurement of the $\mathrm{G}+\mathrm{C}$ content of deoxyribonucleic acid by high-performance liquid chromatography. Int J Syst Bacteriol 39, 159-167.

Naser, S., Thompson, F. L., Hoste, B., Gevers, D., Vandemeulebroecke, K., Cleenwerck, I., Thompson, C. C., Vancanneyt, M. \& Swings, J. (2005a). Phylogeny and identification of enterococci using atpA gene sequence analysis. J Clin Microbiol 43, 2224-2230.

Naser, S. M., Thompson, F. L., Hoste, B., Gevers, D., Dawyndt, P., Vancanneyt, M. \& Swings, J. (2005b). Application of multilocus sequence analysis (MLSA) for rapid identification of Enterococcus species based on rpoA and pheS genes. Microbiology 151, 2141-2150.

Naser, S. M., Hagen, K. E., Vancanneyt, M., Cleenwerck, I., Swings, J. \& Tompkins, T. A. (2006a). Lactobacillus suntoryeus Cachat and Priest 2005 is a later synonym of Lactobacillus helveticus (Orla-Jensen 1919) Bergey et al. 1925 (Approved Lists 1980). Int J Syst Evol Microbiol 56, 355-360.

Naser, S. M., Vancanneyt, M., Hoste, B., Snauwaert, C., Vandemeulebroecke, K. \& Swings, J. (2006b). Reclassification of Enterococcus flavescens Pompei et al. 1992 as a later synonym of Enterococcus casseliflavus (ex Vaughan et al. 1979) Collins et al. 1984, and Enterococcus saccharominimus Vancanneyt et al. 2004 as a later synonym of Enterococcus italicus Fortina et al. 2004. Int J Syst Evol Microbiol 56, 413-416.

Pitcher, D. G., Saunders, N. A. \& Owen, R. G. (1989). Rapid extraction of bacterial genomic DNA with guanidium thiocyanate. Lett Appl Microbiol 8, 151-156.

Stackebrandt, E., Frederiksen, W., Garrity, G. M. \& 10 other authors (2002). Report of the ad hoc committee for the re-evaluation of the species definition in bacteriology. Int J Syst Evol Microbiol 52, 1043-1047.

Tanasupawat, S., Shida, O., Okada, S. \& Komagata, K. (2000). Lactobacillus acidipiscis sp. nov. and Weissella thailandensis sp. nov., isolated from fermented fish in Thailand. Int J Syst Evol Microbiol 50, 1479-1485.

Torriani, S., Felis, G. E. \& Dellaglio, F. (2001). Differentiation of Lactobacillus plantarum, L. pentosus, and L. paraplantarum by recA gene sequence analysis and multiplex PCR assay with $r e c A$ genederived primers. Appl Environ Microbiol 67, 3450-3454.

Ventura, M., Canchaya, C., Meylan, V., Klaenhammer, T. R. \& Zink, R. (2003). Analysis, characterization, and loci of the tuf genes in Lactobacillus and Bifidobacterium species and their direct application for species identification. Appl Environ Microbiol 69, 6908-6922.

Zeigler, D. R. (2003). Gene sequences useful for predicting relatedness of whole genomes in bacteria. Int J Syst Evol Microbiol 53, 1893-1900. 